
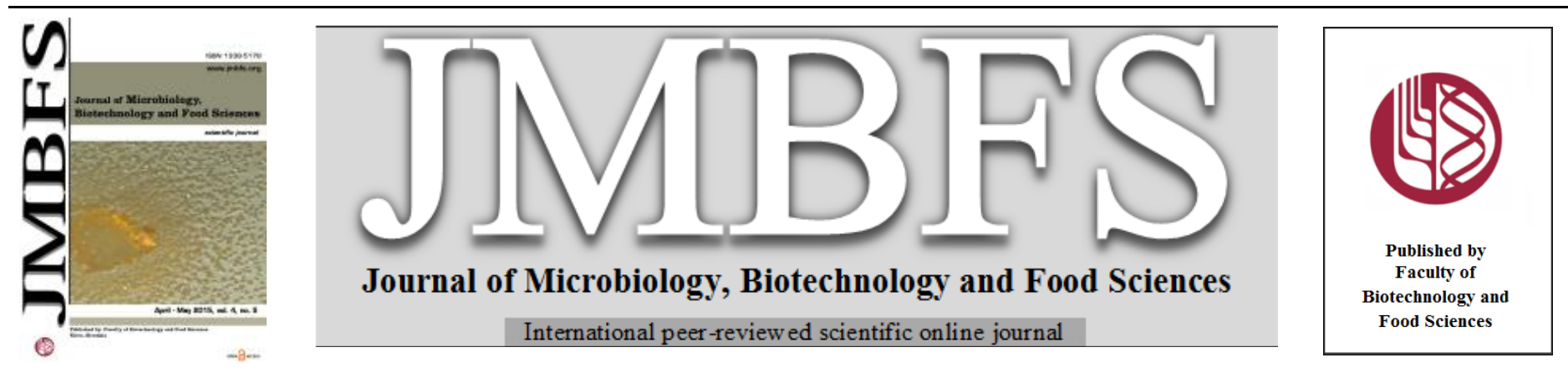

\title{
ANTIBACTERIAL EFFECT OF COMPOUNDS OF PEPTIDE NATURE CONTAINED IN AQUEOUS EXTRACT OF BRASSICA NAPUS SOLANUM LYCOPERSICUM AND TETRAGONIA TETRAGONIOIDES LEAVES
}

\section{Tereza Neubauerová ${ }^{1}$, Ivana Doležilková ${ }^{1}$, Marta Královál, Irina Schevchenko ${ }^{1}$, Anna Macưrkovál, Miloslav Šanda ${ }^{2}$, Petra Loveckál, Martina Mackovál, Tomáš Macek ${ }^{1}$}

\author{
$\operatorname{Address(es):~}$ \\ ${ }^{1}$ Department of Biochemistry and Microbiology, Institute of Chemical Technology, Prague, Technická 5, 166 28, Prague 6, CZ. \\ ${ }^{2}$ Institute of Organic Chemistry and Biochemistry, Czech Academy of Sciences, Flemingovo n. 2, 16610 Prague 6, CZ.
}

*Corresponding author: Tomas.Macek@vscht.cz

doi: 10.15414/jmbfs.2015.4.5.427-433

\section{ARTICLE INFO}

Received 18. 6. 2014

Revised 26. 1. 2015

Accepted 20. 2. 2015

Published 1. 4. 2015

Regular article open $\partial_{\text {ACCESS }}$

\section{ABSTRACT}

Treatment of infections caused by pathogenic bacteria is still harder. Due to increasing number of microbial species resistant against so far invented antibiotics. This presents great problem for public health. One of the potential solutions seems to be antimicrobial peptides. Those peptides are synthetized in all organisms as a part of innate immunity with rapid mode of antimicrobial action. Lot of them have been isolated from bacteria, plants, insects and mammals as well. Our project was aimed on finding such peptides in plant extracts, respectively in leaves of Brassica napus (canola), Solanum lycopersicum (tomato) and Tetragonia tetragonioides (New Zealand spinach). We used several separation techniques to obtain fractions containing compounds of peptide nature with hydrophobic character. Antimicrobial activity of these fractions was tested against several gram-positive and gram-negative bacteria. Mass spectrometry analysis of antimicrobial active fractions proved presence of low molecular peptides with molecular masses 1.9 - $4.9 \mathrm{kDa}$ and a partial amino acid sequence in hydrophobic part of Tetragonia extract. In hydrophilic fraction of the Solanum extract with proved antibacterial activity two patogenesis-related proteins with antifungal activity NP24 and TPM-1 were detected.

Keywords: Antimicrobial peptide, Antibacterial activity, Brassica napus, Solanum lycopersicum, Tetragonia tetragonioides, Diffusion susceptibility testing, Tricine electrophoresis

\section{INTRODUCTION}

Antimicrobial peptides (AMPs) are widely distributed among all organisms as a part of innate immunity. These peptides show broad spectrum of activity. Bacteria, plants, invertebrates and also vertebrates including mammals produce them as a part of their first line of immune defence. They can act against diverse infectious agents including bacteria, yeasts, moulds, parasites, some viruses and even cancer cells (Zasloff, 2002). The activity of AMPs depends on amphipaticity of secondary structure included $\square$-helixes and $\square$-sheets. These structures interact with cell membranes and cause pore forming or its destruction. Some peptides can also attack submolecular structures (RNA, DNA) and cause cell death (Lai \& Gallo, 2009). On March 2013, there were 2183 of such peptides in the database of antimicrobial peptides (APD). In total, there are 1656 AMPs from animals, especially amphibians, 293 from plants, 181 from bacteria, 5 from protozoa and 10 from fungi. For entering the APD, there must be demonstrated antimicrobial activity and its amino acid sequence have to be known at least partially. The APD also collected a number of synthetic peptides (2\%) (Wang et al, 2013).

Antimicrobial peptides could replace some of the common antibiotics used in human and veterinary medicine, the most probably those used in curing topical infections. As an example we can point bacitracin or polymyxins - bacteria AMPs used for decades without any significant case of resistance against them. In contrast to common antibiotics, the advantage of AMPs is rapid mode of action decreasing the ability of bacteria to adapt and create mechanism of resistance. Overloading of antibiotic drugs in human and veterinary medicine led to emergence of the resistant food-borne pathogens and pathogens causing various nosocomial infections during last years. Resistance to nearly all available antibiotics has developed. The alarming occurrence of resistance among bacteria led the World Health Organisation (WHO) to announce antimicrobial drug resistance as a main public health concern (WHO, 1995).

To bacteria, which cause thousands deaths and million cases of food-borne illnesses, belong Staphylococcus aureus resistant to methicillin and vancomycin
(MRSA and VRSA), Streptococcus and Enterococcus resistant to vancomycin and linezolid, and multidrug resistant Salmonella, Campylobacter and Listeria monocytogenes. Rising danger of multidrug resistant strains of gram-negative bacteria like Pseudomonas aeruginosa, Acinetobacter baumanii, Escherichia coli O157:H7 and Klebsiella pneumoniae was recorded (Levin et al., 1999, Wiener et al., 1999, Neonakis et al., 2010).

The other potential use of the AMPs is in plant protection. Concedering the rapidly increasing number of population on Earth, this situation can lead to insufficiency of food. Therefore, contamination and proliferation of food pathogens and protection of food with a new type of antimicrobials are of a great concern for food safety and public health. As for agricultural plants, farmers are facing serious problems with crops loses due to microbial action. Losses on crops caused by pathogens and pests rised up to $45 \%$. Pathogens influence not only the yield but also the quality of the products. For example mycotoxins produced by Asperillus and Fusarium species are toxic for both humans and animals. The control of presence of fungal pathogens on the field of canola (Brassica napus) in 2008 showed surprising results: Sclerotina sclerotinum (81\%), Alternaria brassicaceae (64\%) and Leptosphaeria maculans (35\%) (Verma et al., 2012).

There are used billions tons of pesticides for crop protection. Those compounds persist and pollute environment. On the other hand, biopesticides do not persist because they could be decomposed by natural enzymes. It is known, that plants produce such compounds for self-protection. Here plant AMPs could be mentioned. These peptides are active mainly against bacteria and fungi. Their action is fast, more or less selective, and while useless, they are decomposed by proteases

Crops could be genetically modified by genes for AMPs to improve the defend mechanisms. But approval of GMO crop takes several years and its production is not permitted very often. In European Union production of GMO plants is restricted by strict laws. Nevertheless there already exist some crops with ability of resistace, better taste, nutrition value, bigger yields and storing (Gust et al., 2010). 
One possibility of enhanced AMPs production is induction of natural peptides. As inductors there may be used compounds related to plant stress signal ways as analogues of salicylic or jasmonic acid (Kunkel a Brooks, 2002).

Antimicrobial plant peptides (AMPs) are secreted by various families such as Amaranthaceae, Andropogoneae, Brassicaceae, Oryzeae, Santalaceae, Spermacoceae, Triticeae, Vicieae and Violaceae. Classification has been proposed on the basis of primary structure (Garcia-Olmedo et al., 1998; Castro \& Fontes, 2005). Viola (family Violaceae) and Arabidopsis (family Brassicaceae) appear to be the predominant genera among AMP producers, although this may be due to the extensive studies on these species. Plant AMPs in the database are classified as cyclotides, defensins, hevein-like proteins, knottins, lipid-transfer proteins, shepherins, impatiens, snakins, thionins and vicilin-like proteins (Hammami et al., 2009).

In our research three plants common in moderate climate were chosen - Brassica napus, Solanum lycopersicum and Tetragonia tetragonioides. Brassica napus (canola) belongs to family Brassicaceae, genus Brassica. Brassica is grown mainly in Central Europe, North America, China and India for production of animal food, vegetable oil and biodiesel. Many vegetable plants provide antimicrobial compounds such as antimicrobial peptides and proteins. It is known that vegetables are useful for preventing diseases as well for their curing Brassica napus is used medicinally in chronic coughs and bronchial catarrh (Pandita et al., 2013). Solanum lycopersicum (tomato) belongs to the family Solanaceae, genus Solanum, and grows worldwide, but originally it came from South America. The plant consists of green tall stalk and the red fruits that are used in cuisine worldwide. Because of presence of antioxidants, among them vitamins and carotens, especially lycopene, it is known that these fruits benefit human health (Polivkova et al., 2010). Especially tomato fruits are recommended as valuable source of antioxidants to prevent cancer (Rao et al., 2000).

Tetragonia tetragonioides (New Zealand spinach) belongs to the family Aizoaceae, genus Tetragonia, and grows at temperate and subtropical regions mainly at south hemisphere like New Zealand, Australia, southern Africa and South America. Main parts of this plant are the leaves that have similar flavour and texture properties as spinach (Spinacea oleracea), a consumable vegetable. Tetragonia tetragonioides has been used for treatment of gastric cancer in Eas Asia countries. Recent studies suggest, that this plant effectively inhibits the ulcer formation induced by sedative drugs (Okuyama \& Yamazaki, 1983). Two of cerebrosides have the antiulcerogenic activity (Cambie \& Ash, 1994) and the polysaccharides isolated from the leaves also have antiinflamatory efects (Kato et al., 1985). Tetragonia water extract also showed inhibition of tryptic activity which leads to significant inhibition of trypsin-induced TNF- $\square$ (Tumor necrosis factor $\square$ ) in HMC-1 cells (mast cells) (Kang et al., 2005). Tetragonia tetragonoides has negligible economic importance in many countries in Europe and throughout the world. The investigations by Kmiecik and Jaworska (1999) show, it is worth to propagate Tetragonia because of its high and uniform yields and value and to recommend it for the food processing industry (Jaworska \& Słupski, 2001).

\section{MATERIALS AND METHODS}

\section{Plant material}

The plants of Brassica napus (canola), Solanum lycopersicum (tomato) and Tetragonia tetragonioides (New Zealand spinach) were grown in greenhouse of Institute of Experimental Botany Academy of Sciences of Czech Republic. They were not treated and the harvest was before the flowering time in May. The lenght of the leaves of each plant was about 10 to $15 \mathrm{~cm}$.

\section{Extraction of peptides and proteins from leaves}

Leaves of the three plants (200 g of Brassica, $400 \mathrm{~g}$ of Solanum and $800 \mathrm{~g}$ of Tetragonia leaves) were homogenized using liquid nitrogen and used for peptide extraction. Homogenates were extracted by three hours of incubation in an extraction buffer (0.02 M Tris-HCl, $\mathrm{pH} 7.5)$ containing a mixture of inhibitors of proteases (Sigma). Residual plant material was removed by centrifugation (6 000 $\mathrm{x} \mathrm{g}, 15 \mathrm{~min}, 4^{\circ} \mathrm{C}$ ). Proteins and peptides were separated by ammonium sulphate gradient precipitation. First ammonium sulphate was added to crude extract at $30 \%$ of saturation to remove impurities and large proteins forming a pellet $\left(16000 \times \mathrm{g}, 15 \mathrm{~min}, 4^{\circ} \mathrm{C}\right)$, the pellet was discarded. Then $90 \%$ saturation of ammonium sulphate was achieved and the precipitate containing small proteins and peptides were removed by centrifugation $\left(16000 \mathrm{x} \mathrm{g}, 15 \mathrm{~min}, 4^{\circ} \mathrm{C}\right)$. The salt was removed from the pellet by dialysis in a Tris- $\mathrm{HCl}$ buffer $(0.002 \mathrm{M}$ Tris- $\mathrm{HCl}$ $\mathrm{pH} 7.5,4^{\circ} \mathrm{C}$ ) in dialysis tube with cut off $500 \mathrm{Da}$. The buffer was changed 10 times over the course of 1.5 days. The samples were concentrated in a rotation vacuum concentrator $\left(4^{\circ} \mathrm{C}\right)$.

\section{Purification of crude extracts}

The samples were filtered through a $50 \mathrm{kDa}$ Amicon ${ }^{\circledR}$ (Millipore) filter (5000 x $\mathrm{g}, 30 \mathrm{~min}, 4^{\circ} \mathrm{C}$ ) to remove impurities and larger proteins. The next step was separation on a solid phase extraction (SPE) column Chromabond ${ }^{\mathbb{R}} \mathrm{C}_{18}$
(Machery-Nagel). SPE column separated the hydrophobic portion contained in sample by hydrophobic-hydrophobic interaction. Concentration of the peptide/protein was determined by Bradford microassay (Bio-Rad). Per run approximately $2 \mathrm{mg}$ of protein/peptide with added $0.1 \%$ trifluoroacetic acid (TFA) was applied on the column. At first column was washed with $0.1 \%$ TFA water to elute residues of salt and hydrophilic portion of sample (B). Hydrophobic portion of sample (A) bounded to column is eluted with $80 \%$ and $100 \%$ of acetonitrile $(\mathrm{ACN})$ with $0.1 \%$ TFA respectively. The eluted fractions were concentrated in a rotation vacuum concentrator $\left(4^{\circ} \mathrm{C}\right)$, lyophilized and weighed.

\section{Reverse-phase chromatography purification (RP-HPLC)}

Before RP-HPLC separation the samples were dissolved in $0.1 \%$ TFA water to concentration $1 \mathrm{mg} / \mathrm{ml}$ and approximately 200-500 $\mu 1$ was loaded to the column. Samples were separated using HPLC system Hewlett Packard model 1100, computer operated system with Chemstation program. Semipreparative column $(25 \mathrm{~cm} \times 10 \mathrm{~mm} \times 5 \mu \mathrm{m})$ Discovery ${ }^{\circledR}$ BIO Wide Pore $\mathrm{C}_{8}$ (Sigma) was employed. Elution was performed using gradient of $\mathrm{ACN}$ in $0.1 \%$ TFA from 0.8 to $80 \%$ $(\mathrm{v} / \mathrm{v})$ in $75 \mathrm{~min}$ at flow rate $3 \mathrm{ml} / \mathrm{min}$ for hydrophobic portion of the extract, hydrophilic portion was separated in $45 \mathrm{~min}$. The absorbance was monitored at 218 and $280 \mathrm{~nm}$. Eluted fractions were manually collected, concentrated in a rotation vacuum concentrator $\left(4^{\circ} \mathrm{C}\right)$, lyophilized, and reconstituted in $100 \mu 1$ of sterille water before antimicrobial assay and other analysis.

\section{Antimicrobial assay}

Isolated fractions were tested for antimicrobial activity against bacteria causing infections in humans, animals or plants. For antimicrobial assay gram-positive and gram-negative bacteria were chosen: Staphylococcus aureus, a clinical isolate from Department of Clinical Microbiology, University Hospital Bulovka (Prague) and the other strains from the Collection of Microorganisms of the Department of Biochemistry and Microbiology of ICT Prague (DBM) Pseudomonas aeruginosa (DBM 3082), Pseudomonas syringae (DBM 3144), Escherichia coli (DBM 3001), Bacillus megaterium (DBM 3045) and Streptococcus equi zooepidermicus (DBM 1086). Antimicrobial activity was tested using modified radial diffusion method (Lehrer et al., 1991). Bacteria were cultivated in liquid Mueller-Hinton medium with shaking for 8 hours at 28 or $37^{\circ} \mathrm{C}$. In the exponential phase of growth the cell suspensions were diluted to the OD 0.1 at $550 \mathrm{~nm}$. Aliquot of $100 \mu \mathrm{l}$ of prepared microbial suspensions was spread on the Mueller-Hinton agar plate and tested sample was transferred into a pit in agar made by cork borer with diameter $4 \mathrm{~mm}$. The diameters of clear zones representing intensity of inhibition were measured after 24 hours of incubation. As a positive control commercial antibiotics were used: glycopeptide antibiotic vancomycin against gram-positive and aminoglycoside kanamycin against gramnegative bacteria.

\section{Tricine gel electrophoresis}

Tricine-SDS-PAGE compared to classical SDS-PAGE contains tricin (NTris(hydroxymethyl)methylglycine) in the cathode buffer, that make it suitable for separation of low molecular peptides to 1-2 kDa. Tricine-SDS-PAGE was performed in an electrophoretic system Mini Protean II (Bio-Rad). Tricine electrophoresis method based on protocol (Schägger, 2006) was modified and the ingredients for gel preparation are in the table 1 . Samples $(7 \mu 1)$ were mixed with $7 \mu \mathrm{l}$ reducing sample buffer and denaturised at $95^{\circ} \mathrm{C}$ for $5 \mathrm{~min}$. Inner cathode buffer contained SDS $(1 \%)$, Tris $(1.21 \%)$, Tricine $(1.79 \%)$, pH was not adjusted. Anode buffer contained Tris (24.2\%), pH 8.9. Discontinuous electroforesis was performed in two steps: $20 \mathrm{~min}$ at $30 \mathrm{~V}$ and then $45 \mathrm{~min}$ at 140 V. After electrophoresis the gels were stained by Coomassie Brilliant Blue or silver. The used molecular weight marker was Mark12 ${ }^{\mathrm{TM}}$ Unstained Standard (Invitrogen).

Table 1 Indredients for preparation of 2 gels $(7 \mathrm{~cm} \mathrm{x} 10 \mathrm{~cm} \times 0.75 \mathrm{~mm})$ for Tricine-SDS-PAGE.

\begin{tabular}{lcc}
\hline Ingredient & Separating gels & Stacking gels \\
\hline AB-3 $[\mathrm{ml}]$ & 2.5 & 0.25 \\
Gel buffer $3 \times[\mathrm{ml}]$ & 2.5 & 0.75 \\
Ultrapure water $[\mathrm{ml}$ & 2.5 & 2 \\
APS $10 \%[\mu 1]$ & 25 & 20 \\
TEMED $[\mu 1]$ & 10 & 3 \\
\hline
\end{tabular}

Legend: AB-3 - mixture of akrylamid (48\%) and bis-akrylamid (1.5\%), APS - amonium persulfate, TEMED - $\mathrm{N}, \mathrm{N}, \mathrm{N}^{\prime}, \mathrm{N}^{\prime}$ - tetramethylethylenediamine

\section{Mass spectrometry analysis}

Mass spectra of the isolated fractions were recorded using a hybride FT-HR mass spectrometer LTQ Orbitrap XL (Thermo). Samples dissolved in acetonitrile/0.1\% formic acid in water $(1: 1, \mathrm{v} / \mathrm{v})$ were injected into the mobile phase of the same composition at a flow rate of $100 \mu \mathrm{l} / \mathrm{min}$. The electrospray ion source was operated in positive ion mode with ESI voltage and capillary voltage at 4500 and 
$30 \mathrm{~V}$, respectively. Nitrogen was used as the sheath, auxiliary, sweep and collision gas. The capillary temperature was $280^{\circ} \mathrm{C}$. In the MS mode, the collision energy was set at $10 \mathrm{~V}$. Fractions were MS de novo sequenced using $\mathrm{CID}$ fragmentanion. Fragmentation mass spectra were measured using by in FT mass spectrometry mode with resolution 100000 . Fragmentation spectra were processed by "peak" sofware (Thermo).

\section{RESULTS}

\section{Isolation of antimicrobial peptides and small proteins from plant leaves}

As a source of peptides and small proteins with antimicrobial activity the green parts of plants, respectively the leaves were chosen. Total sum of leaves was $200 \mathrm{~g}$ for Brassica, $400 \mathrm{~g}$ for Solanum and $800 \mathrm{~g}$ for Tetragonia. Biomasses were homogenized and extracts were prepared as described before. After the separation of small proteins and peptide by $90 \%$ ammonium sulphate saturation, the sample was separated using SPE column to a hydrophobic and hydrophilic portion. The ratio of the peptides/protein content in hydrophobic and hydrophilic portion differ at each plant; the yields are summarized in table 2 .

Table 2 Yields of peptides and proteins in the hydrophobic and hydrophilic portion of leaves extract after SPE purification.

\begin{tabular}{lcccc}
\hline $\begin{array}{l}\text { Peptides/protein } \\
{[\mathrm{mg}]}\end{array}$ & $\begin{array}{c}\text { Hydrophobic } \\
\text { portion }\end{array}$ & $\begin{array}{c}\text { Hydrophilic } \\
\text { portion }\end{array}$ & $\begin{array}{c}\text { Total } \\
\text { protein }\end{array}$ & $\begin{array}{c}\text { Total protein } \\
\text { per 100 g of } \\
\text { biomasses }\end{array}$ \\
\hline $\begin{array}{l}\text { Brassica napus } \\
\begin{array}{l}\text { Solanum } \\
\text { lycopersicum }\end{array}\end{array}$ & 2.4 & 7.2 & 9.6 & 4.8 \\
$\begin{array}{l}\text { Tetragonia } \\
\text { tetragonioides }\end{array}$ & 6.9 & 8.8 & 15.7 & 3.9 \\
\hline
\end{tabular}

The hydrophobic and the hydrophilic portions of the each extract were separated using RP-HPLC. Mostly the peaks were well separated so we were able to collect 30 of hydrophobic and 9 of hydrophilic fractions from Brassica, 20 of hydrophobic and 3 of hydrophilic fractions from Solanum and 28 of hydrophobic and 8 of hydrophilic fractions from Tetragonia. The hydrophilic portion contained compounds eluted to $12 \mathrm{~min}$ with absorbance at 220 and $280 \mathrm{~nm}$, contrary the hydrophobic portion of the extract contained compounds of hydrophobic character with elution time from 20 to 60 minutes depending on the type of plant (Fig. 1-6).

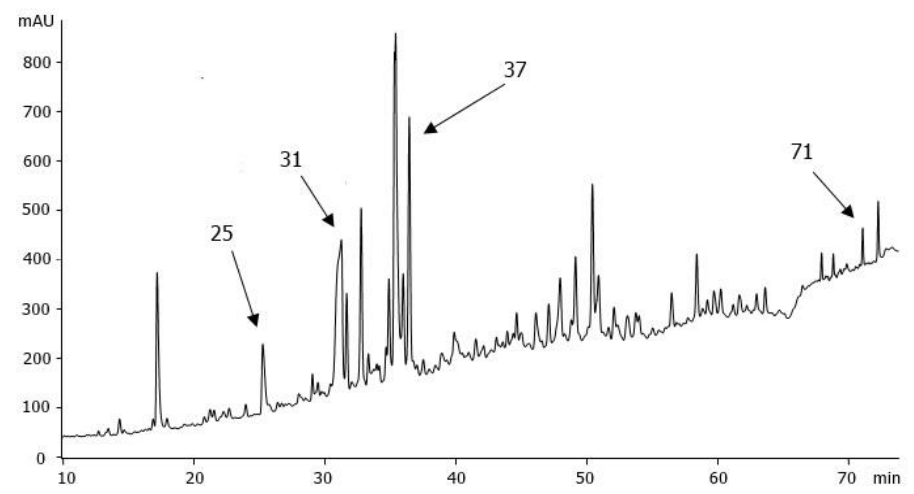

Figure 1 Chromatogram of hydrophobic portion of the Brassica napus extract. Active fractions are marked with arrow.

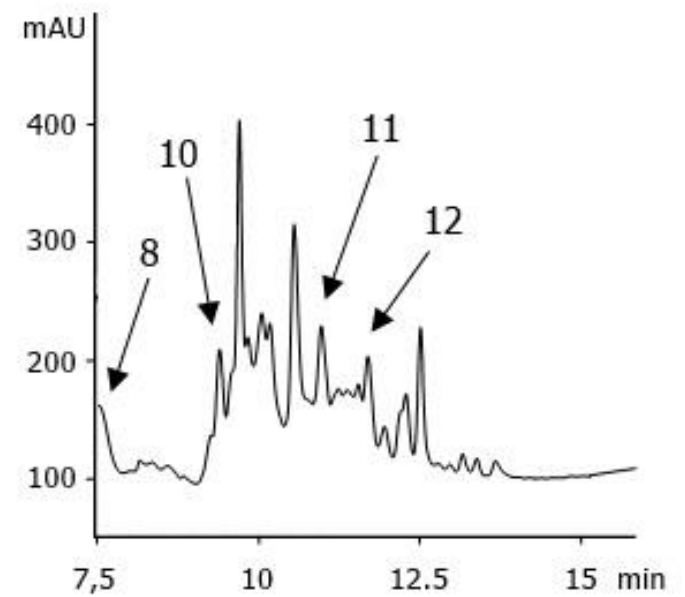

Figure 2 Chromatogram of hydrophilic portion of the Brassica napus extract. Active fractions are marked with arrows.

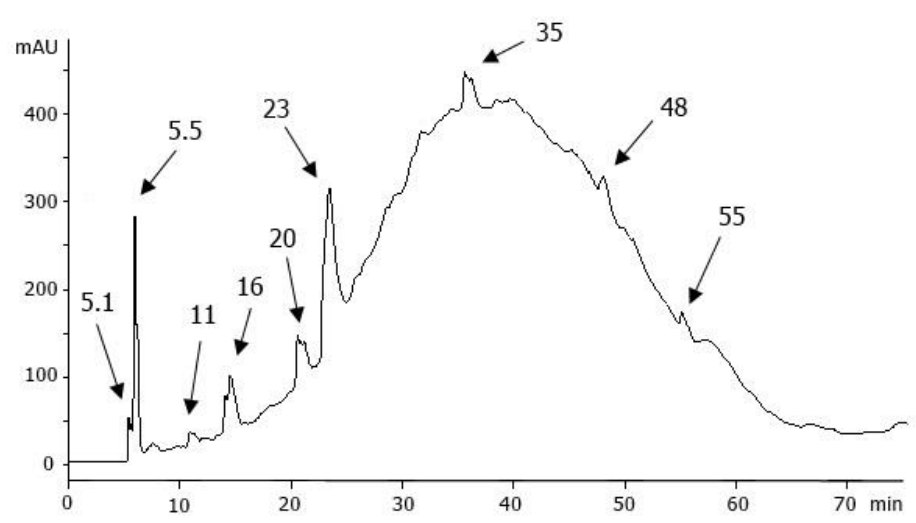

Figure 3 Chromatogram of hydrophobic portion of the Solanum lycopersicum extract. Active fractions are marked with arrows.

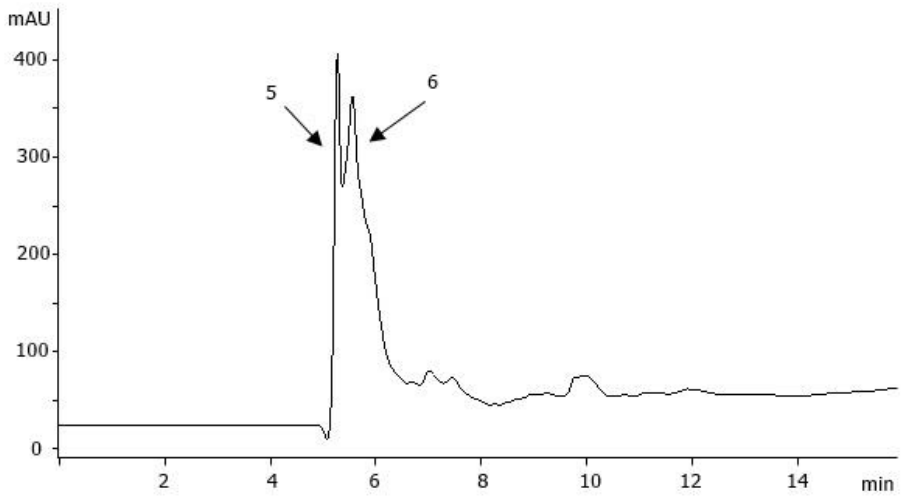

Figure 4 Chromatogram of hydrophilic portion of the Solanum lycopersicum extract. Active fractions are marked with arrows.

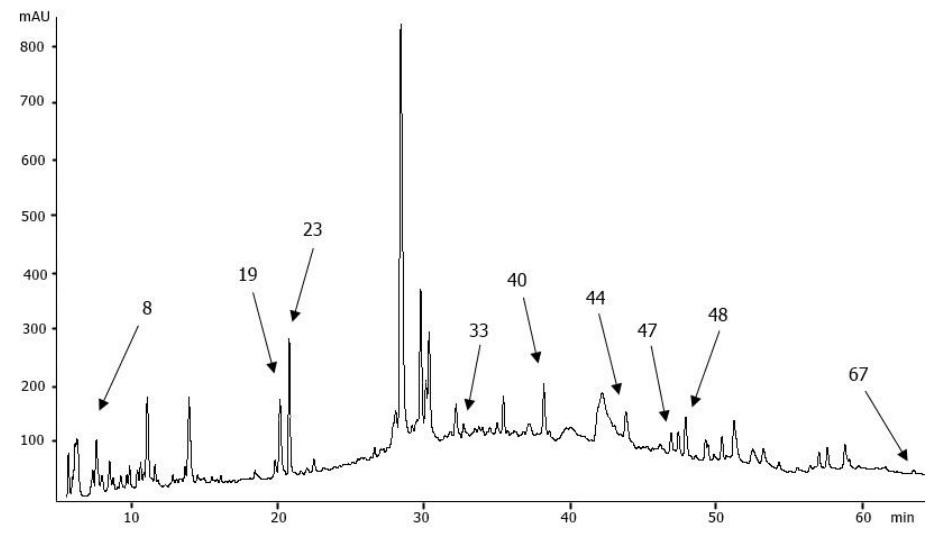

Figure 5 Chromatogram of hydrophobic portion of the Tetragonia tetragonioides extract. Active fractions are marked with an arrows.

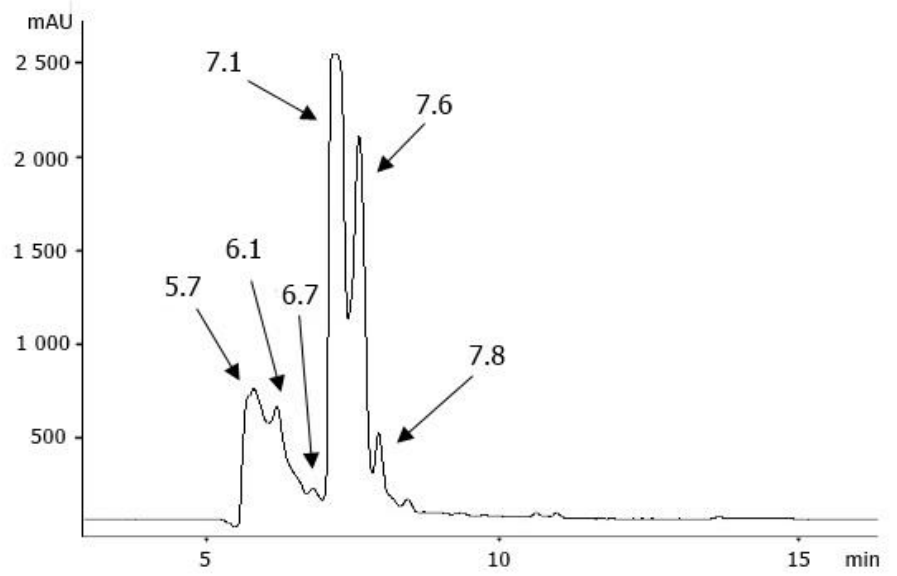

Figure 6 Chromatogram of hydrophilic portion of the Tetragonia tetragonioides extract. Active fractions are marked with arrows. 


\section{Antimicrobial activity}

The fractions isolated by RP-HPLC from the Brassica extract were tested against gram-positive bacteria Staphylococcus aureus, Bacillus megaterium, and gramnegative bacteria Pseudomonas syringe. Only four fractions after separation by RP-HPLC of hydrophobic portion of Brassica sample revealed antimicrobia activity. All four ones with retention time 25, 31, 37 and 71 min inhibited growth of gram-positive bacteria Bacillus megaterium. Two of them with retention time 25 and 71 min inhibited also growth of gram-negative bacteria Pseudomonas syringe. Fractions after separation by RP-HPLC of hydrophilic portion of Brassica sample with retention time between 8 and 12 min revealed antimicrobia activity mainly against gram-negative bacteria Pseudomonas syringe. Results from antimicrobial assay of Brassica sample are in table 3.

Table 3 Antimicrobial activity of fractions after RP-HPLC separation of hydrophobic and hydrophilic sample from the Brassica napus extract in the concentration $10 \mu \mathrm{g} / \mathrm{ml}$.

Inhibition zone $[\mathrm{mm}]$

$\begin{array}{lccc}\begin{array}{l}\text { Retention time } \\ \text { [min] }\end{array} & \begin{array}{c}\text { Bacillus } \\ \text { megaterium }\end{array} & \begin{array}{c}\text { Staphylococcus } \\ \text { aureus }\end{array} & \begin{array}{c}\text { Pseudomonas } \\ \text { syringae }\end{array}\end{array}$

\begin{tabular}{llll}
\hline \hline hydrophobic fractions & & & \\
25 & 8 & 0 & 7 \\
31,37 & 6 & 0 & 7 \\
71 & 8 & 0 & 7 \\
hydrophilic fractions & & 7 & 6 \\
8 & 8 & 0 & 7 \\
$10 ; 11$ & 0 & 7 & 0 \\
12 & 0 & & \\
Vancomycin & 10 & 0 & 8 \\
{$[10 \mu \mathrm{g} / \mathrm{ml}]$} & & & \\
Kanamycin & 0 & \\
{$[20 \mu \mathrm{g} / \mathrm{ml}]$} &
\end{tabular}

During isolation from Solanum extract the hydrophobic and hydrophilic portions after separation on SPE column were screened for antimicrobial activity using radial diffusion against gram-positive bacteria Staphylococcus aureus, Bacillus megaterium, Streptococcus equi zooepidermicus and gram-negative bacteria Escherichia coli and Pseudomonas syringe. Zones of inhibition were detected against at all tested bacteria (tab. 4), but the most intensive zones were detected against gram-positive bacteria Bacillus megaterium (fig. 7) and Streptococcus equi zooepidermicus.
Table 4 Antimicrobial activity of hydrophobic and hydrophilic portions after SPE separation of extract from the Solanum lycopersicum.

\begin{tabular}{lcc}
\hline \multirow{2}{*}{ Tested microorganism } & \multicolumn{2}{c}{ Inhibitory zone diameter [mm] } \\
\cline { 2 - 3 } & Hydrophobic & Hydrophilic \\
\hline \hline Staphylococcus aureus & 8 & 7 \\
Bacillus megaterium & 10 & 15 \\
Streptococcus & 10 & 10 \\
equizooepidemicus & 5 & 7 \\
Escherichia coli & 7 & 0 \\
Pseudomonas syringe &
\end{tabular}

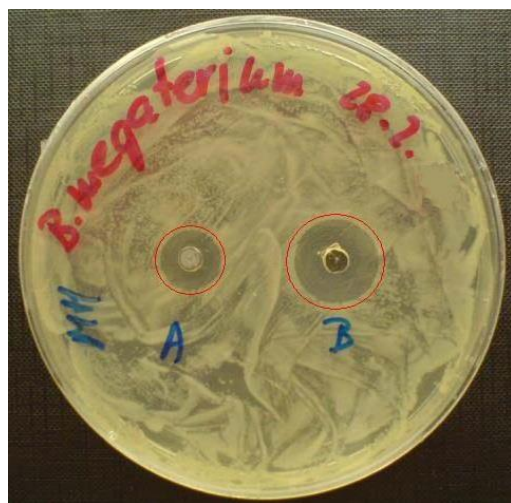

Figure 7 An example of antimicrobial assay using modified radial diffusion method against bacteria Bacillus megaterium. Tested samples are the hydrophobic (A) and the hydrophilic (B) portion of the Solanum lycopersicum extract after separation on the SPE column (Chromabond $\mathrm{C}_{18}$ ) in the concentration of $1 \mathrm{mg} / \mathrm{ml}$.

Fractions after RP-HPLC separation of Solanum extract were tested against gram-positive bacteria $S$. aureus, B. megaterium, Str. equi zooepidermicus and gram-negative bacteria $E$. coli in the concentration $10 \mu \mathrm{g} / \mathrm{ml}$. Fractions contained in the hydrophilic portion of the Solanum extract with retention time 5 and 6 min showed inhibition of growth of B. megaterium. In the hydrophobic portion were detected more fraction with antibacterial activity. Fraction with low retention time about $5 \mathrm{~min}$ inhibited growth of E. coli and $S$. aureus so as fraction with retention time $55 \mathrm{~min}$. The largest inhibitory zones were observed at the fractions with retention time 11,35 and 48 min against bacteria $B$. megaterium and $S$. aureus. Fractions that significantly inhibited growth of bacteria of all tested spectrum had retention times 20 and $23 \mathrm{~min}$. All results from antimicrobial assay of the Solanum sample are in table 5.

Table 5 Antimicrobial activity of fractions after RP-HPLC separation of hydrophobic and hydrophilic sample from Solanum lycopersicum extract in the concentration $10 \mu \mathrm{g} / \mathrm{ml}$.

\begin{tabular}{lcccc}
\hline \hline \multirow{2}{*}{ Retention time [min] } & \multicolumn{4}{c}{ Inhibition zone [mm] } \\
\cline { 2 - 5 } & Bacillus megaterium & Staphylococcus aureus & $\begin{array}{c}\text { Streptococcus } \\
\text { equizooepidermicus }\end{array}$ & Escherichia coli \\
\hline \hline hydrophobic fractions & 7 & & & 5 \\
\hline 5.1 & 0 & 0 & 0 & 6 \\
5.5 & 10 & 0 & 0 & 0 \\
11 & 8 & 7 & 0 & 8 \\
16 & 9 & 0 & 9 & 0 \\
$20 ; 23$ & 10 & 9 & 0 & 5 \\
$35 ; 48$ & 7 & 0 & 0 & 0 \\
55 & 8 & 0 & 0 & 0 \\
\hline hydrophilic fractions & & 0 & 8 & 6 \\
\hline Vancomycin $[10 \mu \mathrm{g} / \mathrm{ml}]$ & 10 & 7 & & 0 \\
Kanamycin $[10 \mu \mathrm{g} / \mathrm{ml}]$ & 0 & 0 & & \\
\hline \hline
\end{tabular}

Separation of hydrophobic portion of the Tetragonia extract by RP-HPLC revealed antimicrobial fractions eluted mostly between 33 to $48 \mathrm{~min}$. These fractions were tested for antimicrobial activity against one gram-positive (Staphylococcus aureus) and gram-negative (Pseudomonas aeruginosa) bacteria in the concentration $20 \mu \mathrm{g} / \mathrm{ml}$. Results of antimicrobial activity of fractions from Tetragonia extract are in table 6. Most detected antimicrobial activity was agains bacteria (Staphylococcus aureus) at retention time 47 and 48 min and fraction eluted at high concentration of acetonitrile (retention time $67 \mathrm{~min}$ ). Antimicrobial activity was observed also at fraction with retention time to $10 \mathrm{~min}$ at hydrophobic and hydrophilic sample against Staphylococcus aureus and Pseudomonas aeruginosa. 
Table 6 Antimicrobial activity of the fractions after RP-HPLC separation of the hydrophobic and the hydrophilic portion of Tetragonia tetragonioides extract was tested in the concentration $20 \mu \mathrm{g} / \mathrm{ml}$.

\begin{tabular}{|c|c|c|c|}
\hline \multirow{2}{*}{ Retention time [min] } & \multirow{2}{*}{$\mathrm{M}_{\mathrm{W}}[\mathrm{Da}]$} & \multicolumn{2}{|c|}{ Inhibition zone [mm] } \\
\hline & & Staphylococcus aureus & Pseudomonas aeruginosa \\
\hline \multicolumn{4}{|l|}{ hydrophobic fractions } \\
\hline 8 & $\mathrm{LMw}$ & 9 & 5 \\
\hline $19 ; 23$ & $\mathrm{~N}$ & 0 & 5 \\
\hline 33 & $\mathrm{~N}$ & 5 & 0 \\
\hline 40 & 3101.3 & 5 & 7 \\
\hline 44 & 1932.9 & 0 & 6 \\
\hline 47 & 3455.4 & 7 & 0 \\
\hline 48 & 4894.0 & 8 & 0 \\
\hline 67 & $\mathrm{~N}$ & 6 & 0 \\
\hline \multicolumn{4}{|l|}{ hydrophilic fractions } \\
\hline $5.7 ; 6.1 ; 6.7$ & $\mathrm{~N}$ & 0 & 5 \\
\hline 7.1 & 112.05 & 7 & 7 \\
\hline 7.6 & $\mathrm{LMw}$ & 0 & 7 \\
\hline $7.8 ; 11$ & $\mathrm{~N}$ & 0 & 5 \\
\hline Vancomycin $[10 \mu \mathrm{g} / \mathrm{ml}]$ & & 7 & 0 \\
\hline Kanamycin $[20 \mu \mathrm{g} / \mathrm{ml}]$ & & 0 & 8 \\
\hline
\end{tabular}

Legend: $\mathrm{LMw}$ - fraction contained a mixture of low molecular weight substances, $\mathrm{N}$ - not determined.

\section{Characterization}

Tricine electrophoresis of hydrophobic and hydrophilic portion Tetragonia and Brassica and hydrophobic portion of Solanum was performed, but only a few bands could be analyzed by mass spectrometry resulting to no fingerprint data corresponding with the data in the databases, probably due to the low concentrations of fractions after RP-HPLC separation. The electrophoresis of the hydrophilic portion of Solanum extract showed several bands (fig. 8), which were characterized successfully. The bands revealed two common proteins: cystein proteinase 3 (Q40143, EC 3.4.2.-) and glutamate dehydrogenase (P93541, EC 1.4.1.3) and two antifungal patogenesis related proteins: osmotin-like protein TPM-1 (Q01591) and thaumatin-like protein NP24 (P12670). Characterization of NP24 and TPM-1 by mass spectrometry was with score 10.1 .

Some antimicrobial active fractions after RP-HPLC separation of the hydrophobic portion of the Tetragonia extract provided molecular masses corresponding to the masses of the antimicrobial peptides. Fractions with the retention time 40, 44, 47 and 48 minutes contained peptides with molecular masses 3.10, 1.93, 3.46 and $4.89 \mathrm{kDa}$. In fraction with retention time 44 minutes partial amino acid sequence of LPV was determined which correspond to $17 \%$ of the total molecular mass. In the other fractions only low molecular compounds were found. Detail results are in the table 6 .

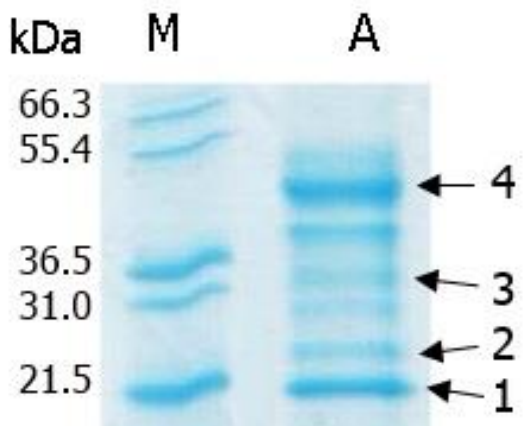

14.4

6.0

Figure 8 Tricine electrophoresis of marker Mark $12(\mathrm{M})$ and the hydrophilic portion of the Solanum extract after SPE separation. Arrows show the bands with detected homology with the following proteins: osmotin-like protein TPM-1 (1 $25840 \mathrm{Da}$ ), thaumatin-like protein NP24 (2 - $26646 \mathrm{Da})$, cystein proteinase 3 (3 - $38945 \mathrm{Da})$, glutamate dehydrogenase (4 - $44813 \mathrm{Da}$,).

\section{DISCUSSION}

Suppression of antimicrobial resistance to antibiotics is huge problem worldwide, but not the only one in connection with infections. As for agricultural plants, farmers are facing serious problem with crop losses due to microbial action. There are used billions tons of pesticides for crop protection. The problem is those compounds persist and pollute environment. On the other hand, biopesticides on peptide base could be induced by action of certain pest in situ in attacked plant, their action is very fast and selective and what is more, while they are not necessary, their decomposition is ensured by hydrolases. Plants are important source of antimicrobial compounds potentially useful in development of new chemotherapeutic agents in human and veterinary medicine and food or crop protection. The first step towards this goal is the in vitro antibacterial activity assay of the substances from the extracts of the naturally occurring plants. Some of these observations have helped to identify potential and new antimicrobials earlier. Some defensin-like peptides has been isolated from the Brassica napus earlier. Plant defensins represent a family of antimicrobial peptides 45-54 amino acid residues in length. All known members of this family have eight disulfide-linked cysteins, including one at the C-terminus (GarciaOlmedo et al., 1998).

Although tomatoes are widely used there has been described only six antimicrobial peptides and proteins and one precursor yet: defensin-like protein (48 aa), gamma-thionin (72 aa), lipid transfer-like protein (94 aa), snakin-2 precursor (104 aa), osmotin-like protein TPM-1 (238 aa), patogenesis-related protein 6 (159 aa) and NP24 (247 aa). Three of them (NP24, TPM-1 and pathogenesis-related leaf protein 6) are antifungal and three, the non-specific lipid transfer protein, gamma-thionin and defensin-like protein are supposed to have antibacterial activity according to similarity of their molecules with members of lipid transfer protein and defensin family (Marcos et al., 2008; Garcia-Olmedo et al., 1998).

From the Tetragonia tetragonioides only 5 proteins have been isolated so far and non of them is antimicrobial. The only antimicrobial peptide isolated from this family is antimicrobial peptide 1 from the Crystalline ice plant (Mesembryanthemum crystallium, genus Mesembryanthemum), that has similarity with knottin family of antimicrobial peptide that form disulphide bridges. This antimicrobial peptide 1 is composed of 64 aminoacids $(7 \mathrm{kDa})$ has antibacterial and antifungal properties.

The biochemical techniques we used for isolation of the plant antimicrobials of peptide nature were based on their properties like size and hydrophobicity. The extraction buffer $0.02 \mathrm{M}$ Tris- $\mathrm{HCl} \mathrm{pH} 7.5$ was set to isolate native peptides/proteins from plant material according to common biochemical techniques. To protect compounds of interest commercial mixture of protease inhibitors was added. In previous extractions we faced problems with antimicrobial activity loses. At first extracted proteins and peptides were separated by $90 \%$ of ammonium sulphate precipitation. This fraction was further separated using hydrophobic interaction on the solid phase extraction column. The yields of the peptide and protein from the hydrophobic and hydrophilic portion were different for each plant. The Tetragonia extract contained almost only hydrophobic portion, contrariwise the Brassica extract contained mostly the hydrophilic portion. In the Solanum extracts the ratio of the hydrophobic and the hydrophilic portion was almost equal. The profile of the chromatograms after RP- 
HPLC separation of the samples was similar between the hydrophobic and the hydrophilic ones and was not determined by the type of plant.

At first we used $200 \mathrm{~g}$ of plant leaves for the extraction at the Brassica, several fractions revealed antimicrobial activity after the RP-HPLC separation, but characterization was unsuccessful. Two times bigger masses were used for Solanum, so we were able to detect not only the antimicrobial activity, but characterize some small proteins in the hydrophilic portion. When making the Tetragonia extract, we used $800 \mathrm{~g}$ of leaves. Then we were able to characterize also some desired peptides with antimicrobial activity in the fractions after RPHPLC separation of the hydrophobic portion. But the concentration of the AMPs in the plants is about $\square \mathrm{M}$ thank to their high effectivity at the low concentrations concentration, so characterising of the complete sequences was unsuccessful. We tested antimicrobial activity of isolated fractions against various bacterial pathogens - the gram-positive bacteria Staphylococcus aureus, Bacillus megaterium and Streptococcus equi zooepidermicus were more sensitive to treatment, but activity against Pseudomonas aeruginosa and Escherichia coli was detected as well.

The fractions after RP-HPLC of the Brassica extract exhibited activity against Bacillus megaterium and the plant pathogen Pseudomonas syringae. The mos active fractions were the ones from the hydrophobic portion with retention time 25 and 71 minutes. The retention time of the last one indicate presence of peptide or protein with very high hydrophobicity. The characterization by mass spectrometry of the Brassica samples was not successful.

Most of the fractions of peptide nature were detected from the Solanum extract, where the portion of hydrophilic and hydrophobic was almost equal Antibacterial assay before RP-HPLC separation revealed very high activity of both - the hydrophilic and the hydrophobic portions - mostly against grampositive bacteria Bacillus megaterium, Streptococcus equi zooepidermicus an Staphylococcus aureus, but against gram-negative bacteria as well (tab. 4). The mass spectrometry analysis of the bands (fig. 8) proved the presence of peptides/proteins homologous with the pathogenesis related antifungal proteins NP24 and TPM-1 with score 10.1. The osmotin-like protein TPM-1 was found during 1990's in leaves of plants of Solanum lycoersicum and is produced during viroid infection (Garcia-Olmedo et al., 1998). The thaumatin-like Solanum lycopersicum protein NP24 was found in the leaves and fruits (Ruiz-Moderano et al., 1992). This pathogenesis related protein is associated with osmotic stress (Rodrigo et al., 1991). These proteins have declared antifungal activity and antibacterial activity (Mohamed $\boldsymbol{e t}$ al., 2011). In future experiments we want to isolate these pure peptides/proteins to specify the antibacterial activity of these pathogenesis related proteins.

The extract of the Tetragonia provided antibacterial properties of the fractions after RP-HPLC separation and their partial characterization. At some fractions with antibacterial activity and very early retention time to 10 minutes the low molecular weights were detected. These fractions probably contain other antimicrobial substances not of peptide origin soluble in water like anthocyanins, tannins, saponins and terpenoids (Cowan, 1999). Presence of desired peptides in hydrophobic fraction was proved at the fraction with the retention time 40, 44, 47 and 48 minutes with molecular weights $3.1,1.9,3.5$ and $4.9 \mathrm{kDa}$ (tab. 6). These fractions inhibited growth of bacteria Staphylococcus aureus and Pseudomonas aeruginosa. Mass spectrometry analysis of the fraction with molecular mass of $1.9 \mathrm{kDa}$ affirmed partial amino sequence $-\mathrm{LPV}-$, that presents approximately $17 \%$ of the total molecular mass. This amino sequence has several similarities in the antimicrobial peptide database (Wang and Wang, 2004; Wang et al., 2009). Most of similarities were with plant cyclotides: isolated from Oldenlandia affinis (kalata peptides) and from a Viola genus (varv peptides, vibi peptides, cycloviolacins, violapeptide 1 and vhl-2).

The results of present investigation clearly indicate that the composition of antibacterialy active fractions containing peptides and small proteins vary with the species of the plants and plant material used, so the screening of the different plants and its parts for antimicrobial activity and characterizing of new antimicrobials with potential use medicine and agriculture is needed.

Agricultural production consumes large amount of pesticides to protect plants and increase yield. If producers are able to induce production of natural antifungal and antibacterial peptides while plants grow, the use of pesticides could be diminished (Sharma at al., 2011). The next aims of our study are identification of antimicrobial active fractions and induction of their production by some stress factors as infection or treatment with compounds stimulating plant immune system.

Acknowledgments: This work was supported by the Czech Science Foundation (project No. 522/09/1693) and Technology Agency of the Czech Republic (project No. TA03010877).

\section{REFERENCES}

CAMBIE, R. C., ASH, J. 1994. Fijian Medicinal plants. CSIRO, Melbourne, Australia. 365 p. ISBN 0-643-05404-9.

COWAN, M. M. 1999. Plant products as antimicrobial agents. Clin Microbiol Rev, 12, 564-570.
GARCIA-OLMEDO, F., MOLINA, A., ALAMILLO, J. M., RODRÍGUEZPALENZUÉLA, P. 1998. Plant defense peptides. Biopolymers, 47(6), 479-491.

GIAMARELLOU H. 2010. Multidrug-resistant gram-negative bacteria: how to treat and for how long. Int $J$ Antimicrob Agents, 36, S50-S54. http://dx.doi.org/10.1016/j.ijantimicag.2010.11.014.

GUST A.A., BRUNNER F., NÜRNBERGER T. 2010. Biotechnological concepts for improving plant innate immunity. Curr Opin Biotech, 21, 204-210. http://dx.doi.org/10.1016/j.copbio.2010.02.004.

HAMMAMI, R.; BEN HAMIDA, J.; VERGOTEN, G.; FLISS, I. 2009 PhytAMP: a database dedicated to antimicrobial plant peptides. Nucleic Acids Res, 37, D963-D968). http://dx.doi.org/10.1093/nar/gkn655

JAWORSKA, G., SŁUPSKI, J. 2001. Badanie przydatności szpinaku nowozelanzkiego do mrozenia. Zywn Nauka Technik, 8, 92-102.

KANG, O., CHOI, Y., PARK, H., TAE, J., KANG, CH., LEE, D., KIM, J., LEE, Y. 2005. Inhibitory effect of Tetragonia tetragonioides water extract on the production of TNF- $\square$ and tryptase in trypsin-stimulated human mast cells Natural Product Sci, 11, 207-212.

KATO, M., TAKEDA, T., OGIHARA, Y., SHIMIZU, M., NOMURA, T., TOMITA, Y. 1985. Studies in the structure of the polysaccharides from Tetragonia tetragonioides. Chem Pharm Bull Jpn, 33, 3675-3679.

KMIECIK, W., JAWORSKA, G. 1999. Effect of growing methods of New Zealand spinach on its yield and pattern of harvests. Folia Horticul, 11, 75-77.

KUNKEL B.N., BROOKS D.M. 2002. Cross-talk between signaling pathways in pathogen defense. Curr Opin Plant Biol, 5, 325-331. http://dx.doi.org/10.1016/s1369-5266(02)00275-3.

LAI, Y., GALLO, R. L. 2009. AMPed up immunity: how antimicrobial peptides have multiple roles in immune defense. Trends Immun, 31, 131-136. http://dx.doi.org/10.1016/j.it.2008.12.003.

LEHRER R. I., ROSEMAN M., HARVIG S. S. S. L., JACKSON R., EISENHAUER P. 1991. Ultrasensitive assays for endogenous antimicrobial polypeptides. J Immunol Methods, 137, 167-173. http://dx.doi.org/10.1016/00221759(91)90021-7.

LEVIN, A. S., BARONE, A. A., PENCO, J., SANTOS, M. V., MARINHO, I. S. ARRUDA, E. A. G., MANRIQUE, E. I., COSTA, S. F. 1999. Intravenous colistin as therapy for nosocomial infections caused by multidrug-resistant Pseudomonas aeruginosa and Acinetobacter baumannii. Clin Infect Dis, 28 , 1008-1014. http://dx.doi.org/10.1086/514732.

MARCOS, J. F., ALBERTO M., ENRIQUE P.-P., SANTOSH M., BELÉN L.-G. 2008. Identification and rational design of novel antimicrobial peptides for plant protection. Аппи Rev Phytopathol, 46, 273-301. http://dx.doi.org/10.1146/annurev.phyto.121307.094843.

MOHAMED, M.S., EL-SOUD, W.A., MOHAMED, M.F. 2011. Cloning and expression of the recombinant NP24I protein from tomato fruit and study of its antimicrobial activity. African J Biotech, 10, 14276-14285.

NEONAKIS I. K., SPANDIDOS D. A., PETINAKI E. 2011. Confronting multidrug-resistant Acinetobacter baumannii: a review. Int J Antimicrob Agents, 37, 102-109. http://dx.doi.org/10.1016/j.ijantimicag.2010.10.014

OKUYAMA, E., YAMAZAKI, M. 1983. The principles of Tetragonia tetragonioides having anti-ulcerogenic activity. II. Isolation and structure of cerebrosides. Chem Pharm Bull, 31, 2209-2214.

PANDITA, D., PANDITA, A., PANDITA, S. 2013. Herbaceous medicinal and therapeutic plants of district Samba of Jammu Province, Jammu \& Kashmir (India). Int J Indig Med Plants, 46, 1224-1238.

POLÍVKOVÁ, Z., ŠMERÁK, P., DEMOVÁ, H., HOUŠKA, M. 2010 Antimutagenic effects of lycopene and tomato purée. J Med Food, 13, 14431450. http://dx.doi.org/10.1089/jmf.2009.0277.

RAO, A., VENKET, AND SANJIV AGARWAL. 2000. Role of antioxidant lycopene in cancer and heart disease. $J$ Am Coll Nutr, 19, 563-569. http://dx.doi.org/10.1080/07315724.2000.10718953.

RODRIGO, I., VERA, P., FRANK, R., CONEJERO, V. 1991. Identification of the viroid-induced tomato pathogenesis-related (PR) protein P23 as the thaumatin-like tomato protein NP24 associated with osmotic stress. Plant Mol Biol, 16, 931-934. http://dx.doi.org/10.1007/bf00015088.

RUIZ-MEDRANO, R., JIMENEZ-MORAILA, B., HERRERA-ESTRELLA, L., RIVERA-BUSTAMANTE, R. F. 1992. Nucleotide sequence of an osmotin-like cDNA induced in tomato during viroid infection. Plant Mol Biol, 20, 1199-1202. http://dx.doi.org/10.1007/bf00028909.

SHARMA P., SINGH A. K., SINGH B. P., GAUR S. N., ARORA N. 2011 Allergenicity assessment of osmotin, a pathogenesis-related protein, used for transgenic crops. J Agric Food Chem, 2011, 59, 9990-9995. http://dx.doi.org/10.1021/jf202265d

VERMA S.S., YAJIMA W.R., RAHMAN M.H., SHAH S., LIU J.J, EKRAMODDOULLAH A.K., KAV N.N. 2012. A cysteine-rich antimicrobial peptide from Pinus monticola (PmAMP1) confers resistance to multiple fungal pathogens in canola (Brassica napus). Plant Mol Biol, 79, 61-74. http://dx.doi.org/10.1007/s11103-012-9895-0.

WANG G. 2013. Database-Guided Discovery of Potent Peptides to Combat HIV1 or Superbugs. Pharmaceuticals, 6, 728-758. http://dx.doi.org/10.3390/ph6060728. 
WANG, G., LI, X., WANG, Z. 2009. APD2: the updated antimicrobial peptide database and its application in peptide design. Nucleic Acids Res, 37, D933D937. http://dx.doi.org/10.1093/nar/gkn823.

WANG, Z., WANG, G. 2004. APD:Antimicrobial peptide database. Nucleic Acids Res, 32, 504-508. http://dx.doi.org/10.1093/nar/gkh025.

World Health Organisation (WHO). 1995. The use of essencial drugs. Sixth Report of the WHO Expert Committee, WHO Tech Rep, 850-862.

WIENER, J., QUINN, J. P., BRADFORD, P. A., GOERING, R. V., NATHAN, C., WEINSTEIN, R. A. 1999. Multiple antibiotic-resistant Klebsilella and Escherichia coli in nursing homes. JAMA, 281, 517-523. http://dx.doi.org/10.1001/jama.281.6.517.

ZASLOFF, M. 2002. Antimicrobial peptides of multicellular organisms. Nature, 415, 389-396. http://dx.doi.org/10.1038/415389a. 